\title{
USTAVNI SUD REPUBLIKE HRVATSKE KAO "EUROPSKI" SUD I OČUVANJE NACIONALNIH STANDARDA ZAŠTITE TEMELJNIH LJUDSKIH PRAVA I SLOBODA
}

Doc. dr. sc. Ana Horvat Vuković*

UDK: 341.231.14(4):342.565.2(497.5)

$342.76 / .77(497.5)$

$342.565 .2(497.5)$

DOI: $10.3935 /$ zpfz.69.2.04

Izvorni znanstveni rad

Primljeno: lipanj 2018.

Autorica analizira fenomen nacionalnih sudova kao "europskih" prvostupanjskih sudova i njime kreiran sustav dvostruke lojalnosti prema europskom i prema nacionalnom ustavnom poretku. U odnosu na problem zaštite viših nacionalnih standarda temeljnih ljudskih prava i sloboda te nacionalnog ustavnog identiteta razmatra proceduralne načine pomirenja Simmenthal doktrine Suda pravde Europske unije i čl. 37. Ustavnog zakona o Ustavnom sudu Republike Hrvatske. Osim snažne sudačke lojalnosti Ustavu identificira mehanizam dvostruke preliminarnosti kao kompromisno rješenje unutar nacionalne proceduralne autonomije koje bi paralelno koristilo mogućnost interlokutorne kontrole Ustavnog suda i provođenja prethodnog postupka pred Europskim sudom. In ultima linea naglašava supremaciju nacionalnog ustava i njegova ustavnog identiteta, koji u svim slučajevima nepomirljivosti europskih $i$ nacionalnih stajališta, unatoč duhu lojalne suradnje $i$ otvorenosti europskom pravu, mora prevladati. S obzirom na to, Ustavni sud Republike Hrvatske mora ojačati doktrinu ustavnog identiteta i izrijekom preuzeti odgovornost nadzora nad ustavnosti europskog prava u odnosu na njega.

Ključne riječi: Ustavni sud Republike Hrvatske, Sud pravde Europske unije, čl. 37. Ustavnog zakona o Ustavnom sudu Republike Hrvatske, ustavni identitet, zaštita temeljnih ljudskih prava i sloboda, dvostruka preliminarnost

* Dr. sc. Ana Horvat Vuković, docentica Pravnog fakulteta Sveučilišta u Zagrebu, Trg Republike Hrvatske 3, Zagreb; ana.horvat@pravo.hr;

ORCID ID: orcid.org/0000-0002-8451-5620 


\section{PROLEGOMENA: NACIONALNI SUDOVI KAO "EUROPSKI" SUDOVI ${ }^{1}$}

Tvrdnja o Europskoj uniji kao novom, autonomnom pravnom poretku razvijena je 1963. godine ${ }^{2}$ kao "središnja točka ... mitova koji se dalje koriste za ideološke svrhe". ${ }^{3}$ Sljedeće godine ex nihilo stvoreno načelo nadređenosti europskih propisa ${ }^{4}$ predstavljeno je kao mehanizam osiguranja jedinstva i učinkovitosti prava Zajednice te jednakosti država članica. ${ }^{5}$ Vrijednost Coste ležala je u nadi da će države članice odobriti to prisvajanje ovlasti Sudu pravde Europske unije (SPEU) i tako nadomjestiti jasan manjak njegova izravnog mandata. ${ }^{6}$ No, doktrina nadređenosti i dalje nije prihvaćena među državama članicama $\mathrm{u}$ odnosu na njihove ustave ${ }^{7}$ te $s$ produbljivanjem europske integracije nailazi na sve artikuliraniji otpor. Naime, nadređenost europskog prava odredbama nacionalnog prava 1970. protumačena je kao da se odnosi i na ustave članica. ${ }^{8}$ Poduprta načelom učinkovitosti, u predmetu Simmenthal II poprimila je i proceduralni karakter kao obaveza nacionalnog suda da zaštiti prava koja Zajednica dodjeljuje pojedincima, uključujući tako da odbije primjenu suprotne odredbe nacionalnog prava. ${ }^{9}$ 1984. obveze sudova nadopunjene su i doktrinom posrednog učinka, koja obvezuje sudove na tumačenje nacionalnog prava u svjetlu prava Zajednice. ${ }^{10}$ Kasnije je Simmenthal doktrina razdvojena od izravnog učinka kroz

1 Ovaj je rad izrađen u okviru znanstveno-istraživačkog projekta "Novi hrvatski pravni sustav" Pravnog fakulteta Sveučilišta u Zagrebu za 2017. godinu.

2 26/62 NV Algemene Transport- en Expeditie Onderneming van Gend \& Loos v Netherlands Inland Revenue Administration, [1963] ECLI:EU:C:1963:1.

3 Rasmussen, M., Revolutionizing European law: A History of the Van Gend en Loos Judgment, International Journal of Constitutional Law, vol. 12, br. 1, 2014., str. 136.

4 C-6/64 Flaminio Costa v. E.N.E.L., [1964] ECLI:EU:C:1964:66.

5 Fabbrini, F., After the OMT Case: The Supremacy of EU Law as the Guarantee of the Equality of the Member States, German Law Journal, vol. 16, br. 4, 2015., str. 1015.

6 Augenstein, D., "Integration Through Law" Revisited: The Making of the European Polity, Routledge, 2016., str. 16 - 17.

7 Ćapeta, T., Nacionalni ustav i nadređenost prava EU u eri pravnog pluralizma, Zbornik Pravnog fakulteta u Zagrebu, vol. 59, br. 1, 2009., str. 68.

8 11/70 Internationale Handelsgesellschaft v. Einfuhr- und Vorratsstelle für Getreide und Futtermittel, [1970] ECLI:EU:C:1970:114, t. 3.

9 106/77 Amministrazione delle Finanze dello Stato v. Simmenthal, [1978] ECLI:EU:C:1978:49, t. $20-22$.

10 14/83 Sabine von Colson and Elisabeth Kamann v. Land Nordrhein-Westfalen, [1984] ECLI:EU:C:1984:153, t. 26. 
razvoj uzgrednog učinka direktiva ${ }^{11}$ i priznavanje prekluzivnog učinka općim načelima prava EU-a. ${ }^{12}$ Zaključak nacionalnog suda o izuzimanju iz primjene nacionalnog pravila koje se ne može protumačiti sukladno pravu EU-a bez prelaženja contra legem granice imat će, dakle, prekluzivne učinke, dok će se supstitucijski učinak očitovati u slučajevima kada postoji jasna, bezuvjetna i precizna europska norma koja može biti primijenjena umjesto nacionalne. ${ }^{13}$

Simmenthal doktrina izravno "novači" nacionalne sudove u redove "čuvara" europskog pravnog poretka. ${ }^{14}$ Nacionalnog suca postavlja u šizofrenu situaciju, pogotovo kada kao nesukladnu pravilu Unije identificira odredbu nacionalnog ustavnog prava. Prema stajalištu SPEU-a, nemoguće je utvrđivati neustavnost odredbe europskog prava pred nacionalnim forumom jer se njezina valjanost ocjenjuje isključivo pred SPEU-om, u odnosu na europski pravni poredak. ${ }^{15}$ Kada je, pak, u pitanju podustavno pravo, utjecaj nacionalnog ustavnog suda je također ograničen jer europsko pravo zahtijeva da sud samostalno primijeni europsku normu, bez potrebe da poštuje prioritet ustavnog suda u nadzoru neustavnosti takvog propisa. ${ }^{16}$ Time je dovršena transformacija nacionalnih sudova u "europske" prvostupanjske sudove, koji se u provedbi načela nadređenosti europskog prava ne oslanjaju na ustavni sud, nego djeluju kao dvostruki agenti $^{17} \mathrm{u}$ izravnoj komunikaciji sa SPEU-om putem čl. 267. TFEU-a i zahtjeva za donošenjem prethodne odluke.

Takav sustav decentraliziranog sudskog nadzora nad zakonima protivan je kontinentalnoj pravnoj praksi u kojoj ustavni sudovi imaju važnost “čuvara

11 Iako direktive nemaju izravan horizontalan učinak, mogu imati popratne učinke na treće stranke, detaljnije vidi u: Chalmers, D.; Davies, G.; Monti, G., European Union Law: Cases and Materials, Cambridge University Press, 2010., str. 268.

12 Rodin, S., Pravo Europske unije i pravni poredak Republike Hrvatske nakon 20 godina hrvatskog Ustava, Inter-University Centre of Excellence, Opatija, Working Paper $\mathrm{H} 2 / 2010$, str. 18.

13 Ibid., str. 20.

14 SPEU, Opinion 1/09, Draft Agreement on the European and Community Patents Court, 8. ožujka 2011., t. 66. EU nema razvijenu mrežu "federalnih" sudova, pa se oslanja na suradnju nacionalnih sudaca; Schütze, R., European Constitutional Law, Cambridge University Press, 2012., str. 289.

314/85 Foto-Frost v. Hauptzollamt Lübeck-Ost, [1987] ECLI:EU:C:1987:452.

16 Simmenthal II, t. 23 - 24.

17 Martinico govori o dvostrukoj "lojalnosti”, Martinico, G., Multiple Loyalties and Dual Preliminary: The Pains of Being a Judge in a Multilevel Legal Order, International Journal of Constitutional Law, vol. 10, br. 3, 2012., str. 872. 
demokracije" od iskušenja pred kojima se može naći politička zajednica ${ }^{18}-$ uključujući ona europska. Štoviše, Simmenthal mandat sročen $\mathrm{je}^{19}$ dovoljno široko da obuhvati i ustavne sudove. ${ }^{20}$ Od njih se zahtijeva da u slučajevima ocjene ustavnosti podustavnih propisa njih (kao i same ustavne odredbe!) protumače u skladu s pravom Unije, pa i u situaciji u kojoj bi se ustavnosudska nadležnost zasnivala na prigovoru neusklađenosti podustavnog propisa s europskim pravom u državama u kojima se takav sukob konstruira kao pitanje ustavnosti (što je slučaj s Republikom Hrvatskom - vidi infra). U tom bi slučaju ustavni sud bio obvezan uputiti prethodno pitanje o tumačenju prava EU-a ako je odgovor na njega "nužan" kako bi mogao presuditi u sporu koji rješava, s obzirom na to da je riječ o sudu protiv čije odluke nema pravnog sredstva u toj državi članici (čl. 267. st. 2. - 3. TFEU-a). Ipak, nacionalni ustavni sudovi pretežno su i dalje "autsajderi" ${ }^{21} \mathrm{~s}$ malim brojem zahtjeva za prethodnim odlučivanjem, izbjegavajući s prijezirom ${ }^{22}$ podvrgavanje SPEU-u.

\section{RAZVOJ ZAŠTITE TEMELJNIH PRAVA NA RAZINI EU-a}

Rana praksa SPEU-a odražavala je manjak interesa za zaštitu ljudskih prava, opravdavajući to činjenicom da ona nisu dijelom Rimskog ugovora. ${ }^{23}$ Takav stav imao je visok potencijal za konflikt s nacionalnim ustavnim sudovima, odlučnima da zaštite nacionalnu ustavnu ravnotežu, tj. nacionalni katalog temeljnih prava od "arogacije ovlasti" ${ }^{4}$ od strane Zajednice. Nepomirljivost tih

18 Bačić, A., Sudac i ustavna demokracija: dr. sc. Jadranko Crnić kao čuvar ustava, u: Kačer, H.; Momčinović, H.; Žuvela, M. (ur.), Liber amicorum in honorem Jadranko Crnić (1928. - 2008.), Novi informator, 2009., str. 29.

19 C-54/96 Dorsch Consult v. Bundesbaugesellschaft Berlin, [1997] ECLI:EU:C:1997:413, t. 23.

20 Claes, M., The National Courts' Mandate in the European Constitution, Bloomsbury Publishing, 2006., str. 453.

${ }^{21}$ Omejec, J., Study on European Constitutional Courts as the Courts of Human Rights: Assessment, Challenges, Perspectives, 3rd Congress of the Association of Asian Constitutional Courts and Equivalent Institutions, Bali, travanj 2016., str. 32.

22 Cartabia, M., "Taking Dialogue Seriously": The Renewed Need for a Judicial Dialogue at the Time of Constitutional Activism in the European Union, Jean Monnet Working Paper, br. 12, 2007., str. 22.

23 Rehman, J., International Human Rights Law, Pearson Education, 2010., str. 248.

24 Weiler, J. H. H., The Transformation of Europe, Yale Law Journal, vol. 100, br. 8, 1991., str. 2417. 
pozicija vidljiva je iz reakcija BVerfGE, koji se još 1967. (obiter) ${ }^{25}$ pozvao na pravo na nadzor nad europskim pravom u tom smislu, te talijanskog Ustavnog suda koji je 1973. uspostavio "controlimiti" doktrinu. ${ }^{26}$ SPEU je na to 1974 . godine u predmetu Nold ${ }^{27}$ započeo inkorporaciju jamstava temeljnih prava "inspirirajući se" zajedničkim ustavnim tradicijama država članica i međunarodnim ugovorima koje su one potpisale ili u čijoj su izradi sudjelovale. Time je išao za zaustavljanjem "korištenja plemenitog cilja zaštite temeljnih prava za neplemeniti cilj obrane suverene nacionalne države protiv europske integracije" ${ }^{28}, \mathrm{tj}$. za time da "izmakne tlo pod nogama" nacionalnim ustavnim sudovima, monopolizirajući ovlast ukidanja mjera inkompatibilnih s temeljnim pravima. ${ }^{29}$ Ipak, petnaest dana kasnije neimpresionirani je BVerfGE jasno odbacio nadređenost europskog prava ustavnim odredbama koje jamče temeljna prava i slobode s obzirom na to da su ona i inače kao dio nepovredive strukture Ustava imuna na prijenos ovlasti na Zajednicu - pogotovo u situaciji u kojoj je zaštita prava na razini Unije neadekvatna. ${ }^{30}$ Dvanaest godina kasnije SPEU je ipak uvjerio BVerfGE da se u Solange II ${ }^{31}$ obveže na suzdržanost sve dok europsko pravo pruža učinkovitu zaštitu koja je "značajno slična” onoj njemačkog Ustava i koja štiti njihov "esencijalni značaj”. ${ }^{2}$ BVerfGE je tako potaknut željom da osigura najviše ustavne standarde zaštite temeljnih prava prisilio SPEU na razvoj prakse koja je u konačnici djelomično i marginalizirala ulogu ustavnih sudova. ${ }^{33}$ Ipak, to je nastojanje SPEU-a od samog početka osuđeno na polovični uspjeh jer je njegova zaštita temeljnih prava vrijednosno razvedena od ustava država članica. Dizajnirana u službi projekta

25 Maduro, M. P.; Azoulai, L. (ur.), The Past and Future of EU Law: The Classic of EU Law Revisited on the 50th Anniversary of the Rome Treaty, Bloomsbury Publishing, 2010., str. 121.

Frontini v. Ministero delle Finance, odluka br. 183/73, 18. prosinca 1973.

27 4/73 J. Nold, Kohlen- und Baustoffgroßhandlung v Commission of the European Communities, [1974] ECLI:EU:C:1974:51.

28 Maduro; Azoulai, op. cit. u bilj. 25, str. 121 - 122.

29 Isiksel, T., Europe's Functional Constitution: A Theory of Constitutionalism Beyond the State, Oxford University Press, 2016., str. 109. Solange I, BVerfGE 37, 271 (2 BvL 52/71), t. 280.

BVerfGE 73, 339 (2 BvR 197/83), t. 378 - 381. U tom kontekstu vidi Grimm, D., Defending Sovereign Statehood Against Transforming the Union into a State, European Constitutional Law Review, vol. 5, 2009., str. 357.

Djelomični engleski prijevod odluke na: https://aw.utexas.edu/transnational/foreign-law-translations/german/case.php?id=572 (14. svibnja 2018.).

33 Rodin, op . cit. u bilj. 12, str. 325. Jednako kao kasnije u kontekstu ultra vires kontrole BVerfGE intervenira tek supsidijarno, nakon što je SPEU imao priliku protumačiti europski propis u skladu s njemačkim ustavnim jamstvima (285), Grimm, op. cit. u bilj. 31, str. 357 . 
integracije, prioritizira tržišne slobode ispred onih klasičnih liberalnih na način nezamisliv konstitucionalizmu posvećenom zaštiti ljudskog dostojanstva. Neoliberalna agenda pri tome se diskursom temeljnih prava služi tek kao krinkom ${ }^{34} \mathrm{i}$ ne prihvaća temeljne slobode i prava kao apsolutne vrednote. ${ }^{35}$

Stupanje na snagu Povelje temeljnih prava omogućilo je SPEU-u da proizvoljno nastupa kao ustavno sudište ${ }^{36} \mathrm{i}$ instrumentalizira diskurs ljudskih prava za daljnju centralizaciju ${ }^{37}$ Puzajuće širenje ovlasti utjelovljeno u predmetu Frann$s{ }^{38}{ }^{38}$ erodira funkcioniranje nacionalnih sudova čak i u situacijama koje su tek "u dosegu" prava EU-a. ${ }^{39}$ Tako proširena primjenjivost Povelje (i nadležnost SPEU-a) omogućuje prisiljavanje članica na usvajanje niže razine zaštite prava od one jamčene njihovim ustavima. ${ }^{40}$ Iako čl. 53. Povelje navodi da "ništa u njoj" neće biti protumačeno na način koji bi ograničio ili nepovoljno utjecao na prava i slobode u opsegu kako ih jamče ustavi članica, to se $n e$ odnosi na situaciju u kojoj je taj nacionalni ustavni standard viši (Melloni, t. 58.). Fiat Europskog suda tako je nadjačao konstitucionalističku ideju, nadređujući ideal "primata, jedinstva i učinkovitosti prava EU-a” (t. 60.) zaštiti temeljnih ljudskih prava. ${ }^{41}$

S obzirom na to da čl. 52. st. 3. Povelje navodi da će njezina prava koja odgovaraju pravima jamčenim Europskom konvencijom imati njima jednako značenje i

34 Komárek, J., Why National Constitutional Courts Should Not Embrace EU Fundamental Rights, LSE Law, Society and Economy Working Papers 23/2014, str. 13 - 14.

35 Cartabia, op. cit. u bilj. 22, str. 7.

36 Ibid., str. 4.

37 Dorota Leczykiewicz govori o proračunatoj centralizaciji koja vodi u budućnost ustavnih sukoba, Melloni and the future of constitutional conflict in the EU, UK Constitutional Law Association Blog, https://ukconstitutionallaw.org/2013/05/22/dorota-leczykiewicz-melloni-and-the-future-of-constitutional-conflict-in-the-eu/ (14. svibnja 2018.).

38 C-617/10 Åklagaren v. Hans Åkerberg Fransson, [2013] ECLI:EU:C:2013:105.

39 Kaczorowska-Ireland, A., European Union Law, Routledge, 2016., str. 246. Unatoč čl. 51. Povelje, kojim su članice njome obvezane isključivo kada "implementiraju" pravo Unije, SPEU je 2013. primijenio mnogo širi koncept pitanja u "dosegu" prava EU-a, OJ C 303/17, 14. prosinca 2007.

40 C-399/11 Stefano Melloni v Ministerio Fiscal, [2013] ECLI:EU:C:2013:107 i vezana odluka španjolskog Ustavnog suda br. 26/2014 od 13. veljače 2014. (BOE-A-2014-2650), u kojoj je reinterpretiran Ustav i snižena zaštita prava na pošteno suđenje kako bi se izbjegao sukob sa SPEU-om.

${ }^{41}$ Besselink, L., The ECJ as the European "Supreme Court”: Setting Aside Citizens' Rights for EU Law Supremacy, Verfassungsblog, 18. kolovoz 2014., na: http://verfassungsblog. de/ecj-european-supreme-court-setting-aside-citizens-rights-eu-law-supremacy (14. svibnja 2018.). 
doseg, jasno je da će Povelja štititi tek najniži zajednički europski nazivnik ljudskih prava. Ustavi država članica često pružaju višu razinu od paneuropskog "poda”, pa ovaj neksus Povelje i Konvencije države sili na snižavanje kriterija zaštite sloboda i primjenu dvaju različitih standarda zaštite istog prava - jednog (nižeg) za situacije "u dosegu" prava EU-a te drugog (višeg) za isključivo domaća pitanja. Kako pokazuju predmeti kao Alemo Herron ${ }^{42}$, osobito ranjiva bit će prava druge generacije oprečna Poveljinu “obožavanju slobode ugovaranja”. ${ }^{43}$ Iako tek tumačenjem SPEU-a izvedena iz "slobode poslovanja"44, sloboda ugovaranja temeljena na ideološkom stavu SPEU-a ugrožava višu nacionalnu razinu zaštite socijalno-ekonomskih prava.

\section{3. "USTAVNI IDENTITET" U OSNIVAČKIM UGOVORIMA I PRAKSI SPEU-a}

Relativizacija supremacije prava EU-a zbila se na dva polja: povijesno starije među njima je praksa nacionalnih sudova utemeljena na želji za zaštitom viših nacionalnih jamstava temeljnih sloboda, koja moraju biti štićena od derogirajućeg učinka europskog prava. Ti napori na impregnaciji nacionalnih standarda s vremenom su postali opsežniji, šireći se i na širu zaštitu čitave nepovredive srži nacionalne ustavnosti. Izvirući još jednom iz prakse BVerfGE, bivajući dalje preuzeta u Deklaraciju $1 / 2004$ španjolskog Ustavnog suda ${ }^{45}$ i vodeći konačno do paneuropskog jamstva čl. 4. st. 2. Lisabonskog ugovora, ta šira strategija zaštite ustavnog DNK-a pojedine nacije napreduje pod egidom očuvanja tzv. ustavnog identiteta. ${ }^{46}$ Privlačnost ove doktrine potvrđuje njezino širenje iz Njemačke i

42 C-426/11 Mark Alemo-Herron and Others v. Parkwood Leisure Ltd., [2013] ECLI:EU:C:2013:521.

43 Weatherill, S., Use and Abuse of the EU'S Charter of Fundamental Rights: on the improper veneration of "freedom of contract", European Review of Contract Law, vol. 10, br. 1, 2014.

44 Bartl, M.; Leone, C., Minimum Harmonisation after Alemo-Herron: The Janus Face of EU Fundamental Rights Review, European Constitutional Law Review, vol. 11, br. 1, 2015. , str. 150.

45 Deklaracija 1/2004 od 13. prosinca 2004. navodi: “u teško zamislivom slučaju u kojem bi buduća dinamika europskog prava postala nepomirljiva sa španjolskim ustavom" Ustavni sud može "kao posljednju opciju [zajamčiti] očuvanje ... vrhovništva španjolskog Ustava”. Ti su potencijalni konflikti tada ocijenjeni neizglednim (II.4.), no vidi odluku 26/2014 (supra, bilj. 40).

Ona predstavlja tek preoblikovanje starije doktrine "neustavnih ustavnih amandmana" u svjetlu odnosa nacionalnog prava i prava EU-a, Faraguna, P., Taking Constitutional Identities Away from the Courts, Brooklyn Journal of Constitutional Law, vol. 41, br. 2, 2016., str. 533. 
Španjolske i u jurisprudenciju najviših sudova Francuske ${ }^{47}$, Češke ${ }^{48}$, Poljske $^{49}$, Portugala $^{50}$, Hrvatske (v. infra), Velike Britanije ${ }^{51}$, Mađarske ${ }^{52}$ te Italije. ${ }^{53}$

Preteču ideje "ustavnog identiteta" na razini prava EU-a možemo pronaći u Maastrichtskom ugovoru iz 1992., koji je u čl. F. st. 1. obvezivao Uniju da poštuje "nacionalne identitete" članica. ${ }^{54}$ Neki autori to jamstvo vezuju uz njemačku ideju osnovne strukture Ustava koja čini temelj njegova identiteta u Solange I odluci, pridajući BVerfGE ulogu "zapovjednika oružanih snaga" najviših nacionalnih sudova. ${ }^{55}$ Lisabonski ugovor 2009. pokušao je dati autonomnu definiciju tih identiteta, inherentnih u državnim "temeljnim strukturama, političkim i ustavnim” (čl. 4. st. 2. TEU-a). Ova dikcija je bliska Solange II, u dijelu u kojem govori o "konstitutivnim strukturama" Ustava. ${ }^{56} \mathrm{~S}$ obzirom na formulaciju čl. 4. st. 2. TEU-a, stručna literatura izjednačava koncept "nacionalnog" s "ustavnim" identitetom. ${ }^{57}$ Ovo supstancijalno jedinstvo je uvjerljivo: ispod površine svakog pravnog poretka leži implicitna društvena teorija. ${ }^{58}$ Ustavi stoga odražavaju tradicije i najdublju svijest njihovih naroda. ${ }^{59}$

Kao osnova osporavanja legalnosti zakonodavnih akata Unije na temelju čl. 263. TFEU-a, nacionalni identiteti služe kao funkcionalna granica intra vires postupanja tijela EU-a. Partikularnost te procedure jest da se sadržaj identiteta nužno razlikuje od jedne države do druge, pa se učinak čl. 263. svodi na omogu-

47 Conseil constitutionnel, odluka br. 2006-540 DC od 27. srpnja 2006., t. 19.

48 US-19/08 od 26. studenog 2008. (t. 109.) i US-29/09 od 3. studenog 2009. (t. 112.).

49 K-32/09 od 24. studenog 2010. i SK-45/09 od 16. studenog 2011.

50 Odluka br. 353/12 od 5. srpnja 2012.

51 Lord Reed (obiter) u predmetu On the application of Buckinghamshire County Council and Others v. The Secretary of State for Transport, [2014] U.K.S.C. 3; par. 110. Slično i lord Mance u predmetu Pham v. Secretary of State for the Home Department, [2015] U.K.S.C. 19; paras. 90 - 91. - Claes, M.; Reestman, J.-H., The Protection of National Constitutional Identity and the Limits of European Integration at the Occasion of the Gauweiler Case, German Law Journal, vol. 16, br. 4, 2015., str. 966.

52 Ustavni sud, odluka br. 22/2016 (XII.5.) AB, od 30. studenog 2016.

53 Corte Costituzionale, Ordinanza br. 24/2017 (Taricco).

54 Treaty on the European Union, OJ C 191/01, 29. srpnja 1992.

55 Faraguna, op. cit. u bilj. 46, str. 522.

56 Claes; Reestman, op. cit. u bilj. 51, str. 933. BVerfGE u Lisabonu iščitava čl. 4. st. 2. TEU-a kao derivat svoje prakse, ibid.

57 Cloots, E., National Identity, Constitutional Identity, and Sovereignty in the EU, Netherlands Journal of Legal Philosophy, vol. 45, br. 2, 2016., str. 83.

58 Komárek, op. cit. u bilj. 34, str. 11.

59 Cartabia, op. cit. u bilj. 22, str. 19. 
ćavanje pojedinačne derogacije od načelnih obaveza na temelju europskog prava. S obzirom na to da SPEU po čl. 19. st. 3(b) TEU-a može tumačiti samo pravo EU-a, nacionalni ustavni sud jedini je nadležan za utvrđivanje predstavlja li neka odrednica ustava dio njegova identiteta. SPEU, pak, utvrđuje relevantnost te komponente $\mathrm{u}$ odnosu na potrebu očuvanja uniformnog učinka europskog prava i jednakosti država članica. Stoga "trivijalne" odredbe nacionalnog ustava neće služiti kao osnove derogacije na temelju čl. 4. st. 2. TEU-a, ali ne zbog neke autonomne procjene SPEU-a koja bi razlikovala bitne od nebitnih elemenata ustava, već zato što bi ti "legitimni ciljevi” u analizi proporcionalnosti na kraju bili nedostatne težine da opravdaju narušavanje tržišnih sloboda ${ }^{60}$ Konačna odluka SPEU-a se, naime, temelji na primjeni načela proporcionalnosti, pa čl. 4. st. 2. TEU-a tek nastavlja već dobro utvrđen pristup Suda ograničavanju temeljnih tržišnih sloboda radi zaštite legitimnih nacionalnih interesa. ${ }^{61} \mathrm{~S}$ obzirom na fundamentalnu važnost nacionalnog ustavnog identiteta, SPEU tu ipak državama članicama odobrava širu marginu diskrecije i veću regulatornu autonomiju.

"Utopljena" u utabanu praksu ograničenog odstupanja od tržišnih sloboda, "identitetska" odredba Ugovora nije spominjana u odlukama SPEU-a sve do preformulacije 2009., iako je bila prisutna u nizu mišljenja nezavisnih odvjetnika. ${ }^{62} \mathrm{U}$ tumačenju M. P. Madura ustupak nacionalnom ustavnom identitetu nije nikakva milost europskih tijela, nego "podsjetnik" na srž europskog projekta, koji počiva na političkoj opstojnosti članica. Povezivanje te opstojnosti s jamstvom "ustavnog identiteta" (Michaniki, par. 31.) jasno govori da je riječ o konstitutivnim elementima državnosti, čija bi relativizacija dovela u pitanje čitavu nacionalnu političku zajednicu. Nacionalna tijela vlasti u najboljem su položaju

60 Suprotno Rodin, koji razmatra tumačenje čl. 4. st. 2. TEU-a koje bi SPEU-u omogućilo upravo takvu "trijažu" nacionalnih ustavnih odredaba, u skladu s kojom bi prilagođavao intenzitet svog nadzora; Rodin, S., Ustavni protekcionizam i nacionalni identitet, u: Ustavi i demokracija: strani utjecaji i domaći odgovori, HAZU, 2012., str. 158 $-159$.

${ }_{61}$ Gdje zaštita elemenata ustavnog identiteta poprima status takvog "legitimnog interesa", ibid., str. 148 i 157. Vidi predmete C-112/00 Schmidberger v. Republic of Austria, [2003] ECLI:EU:C:2003:333 i C-36/02 Omega Spielhallen- und Automatenaufstellungs-GmbH v. Oberbürgermeisterin der Bundesstadt Bonn, [2004] ECLI:EU:C:2004:614, C-391/09 Runevič-Vardyn and Wardyn v. Vilniaus miesto savivaldyb's administracija and Others, [2011] ECLI:EU:C:2011:291 i C-208/09 Ilonka Sayn-Wittgenstein v. Landeshauptmann von Wien, [2010] ECLI:EU:C:2010:608.

62 Npr.Marrosu and Sardino v. Azienda Ospedaliera (C-53/04, [2006] ECLI:EU:C:2006:517; t. 40.) i Michaniki AE v. Ethniko Symvoulio Radiotileorasis and Ypourgos Epikrateias (C213/07, [2008] ECLI:EU:C:2008:731; t. 31.). 
da definiraju komponente ustavnog identiteta (Marrosu and Sardino, par. 40.) i omoguće im da kao protuteža tekućoj konstitucionalizaciji Unije relativiziraju načelo nadređenosti ${ }^{63}$ te funkcioniraju kao "sigurnosni ventil" protiv ustavnih lomova. ${ }^{64} \mathrm{U}$ tome su podložne strogom nadzoru Europskog suda ${ }^{65}$ zaduženog za sprečavanje korištenja klauzule identiteta kao apsolutne rezervacije.

Praksa BVerfGE jasno pokazuje prednosti doktrine ustavnog identiteta. Okolnosti razvoja zaštite specifičnih njemačkih jamstava temeljnih sloboda dobro su poznate te su ukratko već spomenute supra. Praktične implikacije samoobvezivanja BVerfGE u Solange II pojašnjene su 2000. godine Bananenmarkt odlukom $^{66}$, koja je definirala "praktično nepremostive"67 uvjete prihvaćanja nadležnosti BVerfGE na nadzor nad usklađenosti prava EU-a s temeljnim njemačkim jamstvima prava i sloboda. Slučaj tako može biti preuzet samo ako niži sud uvjerljivo, a priori, supstancira tvrdnju da pravo EU-a temeljna prava ne jamči adekvatno. Riječ je o relativno visokim proceduralnim preprekama, koje odražavaju "prijateljski odnos" prema europskom pravu kao njemačku manifestaciju obaveze na iskrenu suradnju.

Takvim proceduralnim i supstancijalnim sužavanjem svojeg kontrolnog djelokruga BVerfGE se 2009. u svjetlu produbljujuće europske integracije našao u potrebi da Lisabon odlukom doda i novo (uz ultra vires, i kontrolu poštovanja nepovredive srži temeljnih ustavnih prava) "oružje" u svojem arsenalu omeđivanja ovlasti tijela EU-a - tzv. Identitätskontrolle. Srž njemačkog ustava, zaštićena “vječnim” jamstvima čl. 79. st. 3. čak i od ustavotvorne ovlasti njemačkog parlamenta, definirana je kao neprenosiva i izolirana od procesa integracije (par. 235.). Takav nadzor nad ustavnim identitetom zahtijeva da se transfer ovlasti prema Uniji ograniči, osobito u vitalnim političkim područjima (par. 251.). U tom smislu impregnirana je sposobnost ustavne države da se demokratski samooblikuje (par. 252.). S obzirom na narav čl. 79. st. 3. Ustava kao "ultimativne granice" (par. 230.) primjenjivosti prava EU-a, Verfassungsidentität ipak

63 Besselink, L., National and Constitutional Identity Before and After Lisbon, Utrecht Law Review, vol. 6, 2010., str. 48.

64 Faraguna, op. cit. u bilj. 46, str. 517.

65 Nadzor se odnosi na dva aspekta klauzule identiteta: praktičnu primjenu testa razmjernosti u situaciji kada Sud prepoznaje učinak europskog propisa na ustavni identitet te odbacivanje provedbe tog testa kada Sud već a priori ne nalazi nikakav njezin nepovoljan učinak (ne ulazeći u točnost nacionalne tvrdnje o elementima ustavnog identiteta) - C-393/10 O’Brien v. Ministry of Justice, [2012] ECLI:EU:C:2012:110; t. 49. BVerfGE 102, 147.

67 Vranes, E., German Constitutional Foundations of, and Limitations to, EU Integration: A Systematic Analysis, German Law Journal, vol. 14, br. 1, 2013., str. 104. 
ne odgovara "nacionalnom identitetu" čl. 4. st. 2. TEU-a te su ta dva koncepta fundamentalno različita. Njemački ustavni identitet u analizi proporcionalnosti ne može biti izložen balansiranju kao puki legitimni cilj koji se mora praktično usklađivati s pravima koja jamči pravo EU-a. ${ }^{68}$ Čl. 4. st. 2. TEU-a stoga nije primjer uspješne "europeizacije controlimiti jurisprudencije" 69 , tj. ne uspijeva pretvoriti sukob nacionalnog prava i prava EU-a u interni sukob dvaju aspekata europskog prava. ${ }^{70}$ No, iako se Identitätskontrolle provodi isključivo u odnosu na okvir njemačkog Ustava, zadržavajući konačnu riječ za BVerfGE ${ }^{71}$, vidljiva je odlučnost BVerfGE da dosljedno primjenjuje ideju prijateljskog odnosa prema europskom pravu. Takav pristup u skladu je s očekivanjima onih koji smatraju da čl. 4. st. 2. kao sudbeno "nuklearno oružje"72 treba postati konstruktivno sredstvo sudbenog dijaloga ${ }^{73}$ i utjeloviti ideal nadzora nad diobom vlasti. ${ }^{74}$

Danas kontrola identiteta zauzima središnji položaj u njemačkom arsenalu ograničavanja daljnje europske integracije. ${ }^{75}$ Tri načelno odvojena mehanizma kontrole međusobno su ipak supstancijalno povezana: kontrolu identiteta možemo promatrati kao naknadni odvjetak ultra vires kontrole, jer svaki europski akt koji vrijeđa njemački ustavni identitet ujedno vrijeđa i načelo prijenosa ovlasti. Iz korpusa jamstava temeljnih prava BVerfGE kontroli identiteta podvrgava tek načelo zaštite ljudskog dostojanstva: tzv. Solange "dva i pol”76 odluka BVerfGE

682 BvR 2728/13, 2729/13, 2730/13, 2731/13 i 13/13 od 14. siječnja 2014., par. 29.

69 von Bogdandy, A.; Schill, S., Overcoming Absolute Primacy: Respect for National Identities Under the Lisbon Treaty, Common Market Law Review, vol. 48, 2011., str. 1426.

70 Faraguna, op. cit. u bilj. 46, str. 500.

71 Suprotstavljanje odluci SPEU-a predstavlja kršenje ugovornih obaveza koje članica ne može opravdati svojim ustavnim pravilima, vidi Rodin, op. cit. u bilj. 60, str. 166. No, to implicira tek odgovornost države za štetu, bez posljedica za valjanost odluke ustavnog suda.

72 Faraguna, op. cit. u bilj. 46, str. 521.

73 Cloots, op. cit. u bilj. 57, str. 96.

74 Millet, F.-X., National Constitutional Identity as a Safeguard of Federalism in Europe, u: Azoulai, L. et al. (ur.), Deconstructing EU Federalism through Competences, EUI Working Papers 2012/06, 2012., str. 59.

75 Claes; Reestman, op. cit. u bilj. 51, str. 922.

76 Goos, C., Solange Zweieinhalb - Teil I, https://www.juwiss.de/14-2016/, 10. veljače 2016. (14. svibnja 2018.). Mathias Hong naziva je Solange III - Human Dignity and Constitutional Identity: The Solange-III-Decision of the German Constitutional Court, Verfassungsblog, https://verfassungsblog.de/human-dignity-and-constitutional-identity-the-solange-iii-decision-of-the-german-constitutional-court/, 18. veljače 2016. (14. svibnja 2018.). 
o europskom uhidbenom nalogu ${ }^{77}$ navodi da će taj Sud provjeravati navod o povredi jamstva ljudskog dostojanstva u kontekstu kontrole ustavnog identiteta u svakom pojedinom slučaju u kojem se ta tvrdnja "detaljno" obrazlaže (paras. 36. i 50.). Pritom se specificiraju i novi proceduralni uvjeti Identitätskontrolle, pa BVerfGE ograničava svoj nadzor na slučaj kada je SPEU imao prethodnu priliku interpretirati sporni akt na temelju čl. 267. st. 3. TFEU-a (par. 46.). Ostaje nam vidjeti u kojem smjeru će se razvijati ovaj konkretni aspekt kontrole identiteta s obzirom na neodređenost "ljudskog dostojanstva", koje se in ultima linea nalazi u srži svakog pojedinačnog ljudskog prava i tako dovodi BVerfGE u iskušenje da zamuti granice dva tipa ustavnosudske kontrole. ${ }^{78} \mathrm{Za}$ sada moramo naglasiti odlučnost BVerfGE da provodi kontrolu identiteta i u slučajevima koji su u potpunosti pokriveni europskim pravom i u kojima bi dosljedna primjena čl. 53. Povelje mogla sniziti razinu zaštite koju pruža nacionalno pravo. ${ }^{79}$ Takva odluka ima veliku simboličku važnost u Uniji koja odbija ratifikaciju Europske konvencije za zaštitu ljudskih prava ${ }^{80}$, i u kojoj predsjednik SPEU-a tvrdi "Sud pravde nije sud za ljudska prava". ${ }^{81}$

\section{USTAVNI IDENTITET U REPUBLICI HRVATSKOJ}

\subsection{Razvoj koncepta u praksi Ustavnog suda}

Doajen hrvatskog konstitucionalizma Branko Smerdel u kontekstu hrvatskog sudjelovanja u europskoj integraciji navodi: "Nacionalni ustav postao je još važniji... [ulaskom u Europsku uniju]. Prethodno smo već upozorili: 'U krivu su oni pravnici koji vjeruju da je istinska jednakost u EU privilegij velikih i snažnih'”. ${ }^{82}$ Prvi koraci u razvoju doktrine ustavnog identiteta učinjeni su u referendumskom pravu, specifično u domeni ustavnosudskog nadzora nad referendumima narodne inicijative pokrenutim na temelju čl. 87. st. 3. Ustava. Prethodno tome,

772 BvR 2735/14 od 15. prosinca 2015.

78 Hong, op. cit. u bilj. 76.

79 Sarmiento, D., Awakenings: the "Identity Control" decision by the German Constitutional Court, Verfassungsblog. https://verfassungsblog.de/awakenings-the-identity-control-decision-by-the-german-constitutional-court/, 27. siječnja 2016. (14. svibnja 2018.).

80 Opinion 2/13 of the Court, 18. prosinca 2014., ECLI:EU:C:2014:2454.

81 Besselink, op. cit. u bilj. 41.

82 Smerdel, B., In Quest of a Doctrine: Croatian Constitutional Identity in the European Union, Zbornik Pravnog fakulteta u Zagrebu, vol. 64, br. 4, 2014., str. 528. 
stavovi pravne struke bili su podijeljeni: dok je kasnija predsjednica Ustavnog suda Omejec zastupala stajalište da hrvatski Ustav ne sadržava "klauzulu vječnosti” 83 , Kostadinov je kao ustavno-identitetsku odredbu identificirala čl. 17. st. 3. i njegovu apoteozu ljudskog dostojanstva, vladavine prava te načela slobodnog demokratskog poretka. ${ }^{84}$ Ustavni sud u svojoj je praksi kao strukturne temelje hrvatske ustavne države označio i čl. 3. s aksiomatskim jamstvima hrvatske ustavnosti ${ }^{85}$, ravnopravnost nacionalnih manjina (st. 2. Izvorišnih osnova) ${ }^{86}$, jamstvo narodnog suvereniteta (čl. 1. $)^{87}$, poštovanje jezika i pisma nacionalnih manjina (čl. 12. st. 2.) ${ }^{88}$ i jamstvo poduzetničke i tržišne slobode (čl. 49. st. 1.). ${ }^{89}$

Katalog tih normi nije zatvoren i Ustavni sud ga nadopunjava od slučaja do slučaja, pa je s vremenom intenzivirao korištenje "ustavnog identiteta" u teleološkoj interpretaciji Ustava. Tako je u odluci iz listopada 2017. preuzeo nadzor nad ustavnošću općeg akta jedinice lokalne samouprave, ne ustupajući predmet Visokom upravnom sudu na način na koji bi to zahtijevalo doslovno tumačenje Zakona o upravnim sporovima. ${ }^{90}$ Pozivajući se na svoju pozitivnu obavezu da "jamči poštovanje i primjenu Ustava” (čl. 2. st. 1. Ustavnog zakona o Ustavnom sudu ${ }^{91}$ ), Ustavni sud će preuzimati nadležnost i u svim slučajevima kada su ugrožene fundamentalne vrijednosti demokratske države utemeljene na vladavini prava i zaštiti ljudskih prava ${ }^{92}$, pa je tako kao sukobljeno s vladavinom prava onemogućeno nazivanje ulice po datumu uspostave NDH kao "nacističke i fašističke tvorevine" (t. 18.). Identitet se također koristi i u izdvojenim mišljenjima ustavnih sudaca, primjerice, kao argument u prilog održavanja (percipirano) višeg standarda zaštite ustavnog prava na život čl. 2l.,

83 Omejec, J., Kontrola ustavnosti ustavnih normi (ustavnih amandmana i ustavnih zakona), Godišnjak Akademije pravnih znanosti Hrvatske, vol. 1, br. 1, 2001., str. 21.

84 Kostadinov, B., Ustavni identitet, u: Barbić, J. (ur.), Dvadeseta obljetnica Ustava Republike Hrvatske, HAZU, 2011., str. 320.

85 Upozorenje u povodu Prijedloga Odluke o raspisivanju državnog referenduma Odbora za Ustav, Poslovnik i politički sustav Hrvatskog sabora od 24. listopada 2013. (U-VIIR-5292/2013 od 28. listopada 2013.), t. 3.

86 Odluka U-I-3597/2010, U-I-3847/2010, U-I-692/2011, U-I-898/2011 i U-I-994/2011 od 29. srpnja 2011., t. 30.1.

87 Upozorenje, loc. cit.

88 Odluka U-VIIR-4640/2014 od 12. kolovoza 2014. ("referendum o ćirilici”), t. 13.1.

89 Odluka U-VIIR-1158/2015 od 21. travnja 2015. (odluka o monetizaciji autocesta), t. 43.1 .

90 Narodne novine, br. 20/2010, 143/2012, 152/2014, 94/2016 i 29/2017.

91 Narodne novine, br. 99/1999, 29/2002 i 49/2002. Dalje u tekstu: UZUS.

92 Odluka U-II-6111/2013 od 10. listopada 2017., t. 10.1. 
a u kontekstu zabrane pobačaja. ${ }^{93}$ Neovisno o vrijednosnoj nepodudarnosti tog stava s našom interpretacijom ustavne ravnoteže između čl. 21. i prava žene na osobno dostojanstvo, autonomiju, slobodu i zdravstvenu zaštitu, ovaj primjer korištenja ustavno-identitetske narative upućuje na njezin potencijal u borbi protiv snižavanja standarda zaštite ljudskih prava pod europskim pritiskom.

Naime, Republika Hrvatska je upravo ulaskom u europsku zajednicu dobila vrlo značajan poticaj za daljnji razvoj teorije ustavnog identiteta. S obzirom na doktrinu nadređenosti europskog acquisa nad svim normama hrvatskog pravnog poretka, vjerujemo da je ustavni identitet idealni kandidat za "konzistentnu branu nepovredive srži hrvatske ustavnosti u europskoj zajednici naroda". ${ }^{4}$ Određenje te neprekoračive granice sudjelovanja u nadnacionalnim integracijama moralo bi biti među prioritetima Ustavnog suda ako želi zaštititi Ustav i predstaviti se kao ozbiljan sugovornik SPEU-a. U tom će smislu razvoj hrvatskog ustavnog identiteta biti nerazdvojno povezan i s evolucijom samog Ustavnog suda u svjetlu logike ustavne države. ${ }^{95}$ Do sada je, ipak, jedini spomen učinaka prava EU-a na hrvatska ustavna jamstva učinjen 2015. godine. U predmetima koji su ocjenjivali ustavnost referenduma narodne inicijative vezanih uz izdvajanje pratećih i neosnovnih djelatnosti u javnom sektoru (tzv. outsourcing) ${ }^{96}$ i monetizaciju hrvatskih autocesta, Ustavni sud je ustvrdio da je "Ustav po svojoj pravnoj snazi iznad prava Europske unije" (t. 45. i 60.). Ovako lakonsko odbacivanje nadređenosti europskog prava smatramo nesmotrenim propustom Suda da pojasni granice učinaka prava EU-a u kontekstu očuvanja specifičnog hrvatskog ustavnog identiteta. Osnovna odrednica svakog, pa i međusudbenog dijaloga, jest međusobno poštovanje sugovornika, pa u tom smislu očekujemo ozbilinije i konstruktivno pristupanje Ustavnog suda.

93 Izdvojeno mišljenje suca Šumanovića, Rješenje U-I-60/1991, U-I-94/1991, U-I173/1995, U-I-39/2008, U-I-5089/2016, U-I-5639/2016 i U-I-5807/2016 od 21. veljače 2017., t. 9.

94 Horvat Vuković, A., "U ime Ustava" - materijalne granice promjene ustava, Zbornik Pravnog fakulteta u Zagrebu, vol. 65, br. 3-4, 2015., str. 491.

95 Horvat Vuković, A., Referendum narodne inicijative 2013. - ustavni identitet kao okvir ustavnosudskog aktivizma, u: Podolnjak, R.; Smerdel, B. (ur.), Referendum narodne inicijative u Hrvatskoj i Sloveniji - Ustavnopravno uređenje, iskustva i perspektive, Hrvatska udruga za ustavno pravo, 2014., str. 149 - 177.

96 Odluka U-VIIR-1159/2015 od 8. travnja 2015. 


\section{2. Čl. 37. Ustavnog zakona o Ustavnom sudu}

$\mathrm{S}$ obzirom na to da u ustavima priznaju nadređenost ratificiranih međunarodnih ugovora svojim zakonima, države monističke tradicije su "relativno lako" prihvatile istovrsnu nadređenost europskog prava. ${ }^{97}$ Ipak, u hrvatskom pravnom poretku ne bismo zasnivali prihvaćanje načelnog prioriteta europskog prava (samo) na odredbi ustavnog čl. 141. S obzirom na federalističku matricu odnosa između država članica i EU-a (vidljivu iz prihvaćanja čl. 142. Ustava kao osnove pristupanja Uniji umjesto čl. 140. st. 2.), zasnivanje nadređenosti prava EU-a na čl. 141. bilo bi neodgovarajuće kvaziustavnom ${ }^{98}$ karakteru prava EU-a i činjenici da se kao prioritetni u našem pravnom poretku ne inkorporiraju tek Ugovori, već i čitavo sekundarno europsko pravo i praksa SPEU-a. To je jasno i iz dikcije 2010. izmijenjenog ustavnog čl. 5., koji navodi dužnost pridržavanja ne samo Ustava već i "prava”. Kako čl. 14l. ne sadržava odredbu koja bi nadzakonsku snagu međunarodnih ugovora automatski protegnula i na sekundarno pravo usvojeno temeljem njih, kao najlogičniji kandidat utemeljenja opsežnog primata cijelog jednog vanjskog pravnog poretka ističe se ustavni čl. 145. Izrastao iz ustavne Promjene 2010. godine, konstitucionalizira izravni učinak prava EU-a (st. 3. i 4.) te prihvaća primjenu pravnih akata i odluka europskih institucija "u skladu s pravnom stečevinom" (st. 2.). Kao takav on je implicitna ustavna osnova nadređenosti prava EU-a ne samo zakonima, već - načelno, $i$ uvjetovano poštivanjem ustavnog identiteta Republike Hrvatske - i odredbama samog Ustava. U svjetlu ustavnih "klauzula vječnosti" i doktrine ustavnog identiteta bilo bi nemoguće toliko pojednostavniti čl. 145. da se protumači kao nekritičko prihvaćanje nadređenosti europskog prava nad ukupnošću Ustava. Bez obzira na sadržaj acquisa na dan hrvatskog pristupanja Uniji, ustavna odluka temeljena na čl. 142. Ustava i prateći ratifikacijski zakon nikako ne mogu raspolagati temeljnim strukturnim odrednicama hrvatske države kojima ne može raspolagati ni ustavotvorac.

Temeljnim pitanjem stoga postaje kako pomiriti načelni prioritet prava EU-a sa zahtjevima očuvanja identiteta hrvatskog Ustava. Ustav Republike Hrvatske ulogu ustavnog kontrolora dodjeljuje isključivo Ustavnom sudu, pa redovni

97 Ćapeta, T., Ustavni acquis communautaire i ustavni poredak Republike Hrvatske, u: Kačer, H.; Momčinović, H.; Žuvela, M. (ur.), Liber amicorum in honorem Jadranko Crnić (1928.-2008.), Novi informator, 2009., str. 228.

98 Prioritet europskog prava pred hrvatskim Ustavom uvjetovan je i ovisi o autonomnoj hrvatskoj interpretaciji granica integracije, zasnovanoj na Ustavu kao jedinom referentnom okviru odlučivanja. U očima SPEU-a učinak prava EU-a je, naravno, nadustavan. 
sudovi suočeni sa zakonskom odredbom koja je neustavna ili protivna međunarodnom ugovoru (uključujući europsko pravo) moraju zastati s postupkom i pričekati završetak postupka ove tzv. interlokutorne ustavnosudske kontrole (čl. 37. UZUS-a). Može li se (i kako) ta obaveza pomiriti sa zahtjevima europskog pravnog poretka ovisi u prvom redu o tumačenju svrhe ustavnozakonskog čl. 37. Ćapeta kao moguće kandidate u tom smislu alternativno navodi mogućnost da se (l) sudovima ne omogućuje ocjena usklađenosti zakona s Ustavom jer bi to moglo rezultirati različitim interpretacijama Ustava ${ }^{99}$, ili da se (2) dosljedno primijeni ustavno načelo diobe vlasti, tj. da se Sabor zaštiti od zadiranja sudova u njegovu zakonodavnu ovlast. ${ }^{100}$ Smatra da prva alternativa ne predstavlja prepreku Simmenthal mandatu s obzirom na to da sudovi stricto sensu ne tumače Ustav, već biraju između dvije podustavne norme (dajući prednost onoj europskoj). S tim u vezi ističemo da prema već polustoljetnom inzistiranju SPEU-a europske norme u svojim očima ne posjeduju tek nadzakonski, već nadustavni karakter. Kao takve, nose ovlast da nadomjeste ili prekludiraju proturječne odredbe nacionalnog ustava, pri čemu svakako može doći do ustavne povrede - ako ne i striktno i ustavne "interpretacije". S obzirom na neprekoračivost ustavnog identiteta, neprihvatljiva je mogućnost da redovni sud učini grijeh izuzimanja iz primjene norme koja pripada identitetskom korpusu. Bilo da je riječ o ustavnoj identitetskoj normi ili zakonskoj normi koja provodi neki od aspekata tog identiteta, potencijal razilaženja (u odnosu na druge redovne sudove te Ustavni sud) u ocjeni njihova odnosa s europskim pravilima ukinuo bi svrhu čl. 37. UZUS-a.

Dalje, predstavljene mogućnosti tek su dva aspekta istog argumenta $\mathrm{u}$ korist centraliziranog ustavnosudskog modela, u kojem povjeravanje nadzora nad ustavnošću propisa isključivo ustavnom sudu smjera na zaštitu legitimnih očekivanja i nearbitrarnosti kao sastavnih komponenti ideje vladavine prava. U supstantivnom značenju vladavina prava je aksiomatsko načelo ustavne države i pripada katalogu hrvatskog ustavnog identiteta. U čl. 37. UZUS-a to načelo osigurava koherenciju pravnog sustava, poimajući Ustavni sud kao mnogo više od nositelja puke defanzivne uloge. Uz zadaću obrane Ustava Ustavni sud ima i "važnu ulogu u kreiranju cjelovitog pravnog poretka", utječući na "promicanje općih mjerila i smjernica za djelovanje javnih vlasti”"101, uključujući sudova. Kao jamac objektivnog poretka vrijednosti on je jedino tijelo ovlašteno na vrijednosno usklađivanje različitih izvora prava u Republici Hrvatskoj, uključujući

99 Ćapeta, op. cit. u bilj. 97, str. 240.

100 Ibid., str. 244.

${ }^{101}$ Omejec, J., O potrebnim promjenama u strukturi hrvatskoj ustavnog sudovanja, u: Barbić, J. (ur.), Hrvatsko ustavno sudovanje, HAZU, 2009., str. 31. 
i europsko pravo kada ono prijeti nepovredivoj srži jamstava temeljnih prava i sloboda. U tom smislu, zaista je riječ o mehanizmu osiguranja diobe vlasti, koji podvrgava svaku od njih - nacionalnu ili europsku, sudbenu ili zakonodavnu načelu zaštite ljudskog dostojanstva (konkretiziranom u jamstvima temeljnih prava i sloboda) kao kupoli ustavnopravnog zdanja.

Vjerujemo da se upravo na takvom tumačenju temelji stav Ustavnog suda o koliziji zakona i međunarodnog ugovora kao pitanju ustavnosti. Počevši od 1998., pitanje međusobne "usklađenosti propisa različite pravne snage koji čine pravni poredak države" 102 pitanje je poštovanja načela vladavine prava čl. 3. Ustava. ${ }^{103}$ Time je pojam "Ustava" čl. 37. st. 1. UZUS-a materijalno proširen i obuhvaća i drugi nadzakonski izvor prava - međunarodni ugovor. S obzirom na ustavni čl. 14l. i nadzakonsku snagu međunarodnih ugovora, Ustavni sud ovom je odlukom neutralizirao opasnost tumačenja koje bi ovlastilo redovne sudove na decentralizirani nadzor zakonitosti u odnosu na hrvatske međunarodnopravne obaveze. Sigurnosni ventil čl. 37. UZUS-a osigurava obavezno odlučivanje Ustavnog suda, koje sprečava mogućnost povreda međunarodnog prava u situacijama u kojima bi redovni sudac pogrešno odlučio da ga hrvatski zakon ne vrijeđa. Također, s obzirom na razvoj teorije ustavnog identiteta, takvo interpretativno rješenje je i više nego nužno kako bi se Ustavnom sudu omogućila zaštita nacionalnog ustavnog DNK-a u slučajevima u kojima zakon nesukladan međunarodnom (uključujući europskom) pravu štiti neki element ustavnog identiteta. S obzirom da primjenjivati "polovičnu dosljednost" znači reducirati taj pojam na razinu apsurda, na ovom mjestu dodajemo i da će Ustavni sud neminovno morati priznati reperkusije ovako utvrđenog telosa čl. 37. UZUS-a (i.e. osiguranja interne koherencije svih izvora prava na teritoriju RH, usklađene s najvišim ustavnim vrednotama) i na svoju nadležnost izravne ocjene materijalne ustavnosti međunarodnih ugovora (uključujući europskog prava). ${ }^{104}$ Vjerujemo, naime, da se svrhovito tumačenje čl. 37. UZUS-a ne može zaustaviti na proširenju kategorije propisa $u$ odnosu na koju se zakoni ocjenjuju (u smislu da se, osim s Ustavom, kontrolira njegova usklađenost i s ostalim nadzakonskim instrumentima kao što su međunarodni ugovori i europsko pravo), već da zahtijeva i proširenje revidirane kategorije propisa. Provjera usklađenosti s Ustavom se na temelju zahtjeva redovnog suda mora provoditi ne samo u odnosu

102 Odluka U-I-745/1999 od 8. studenog 2000.

103 Odluka U-I-920/1995 i U-I-950/1996 od 15. srpnja 1998.

104 Do sada je to odbijao ispričavajući se izostankom izričitog ovlaštenja u čl.129. Ustava, vidi npr. odluku broj U-I-825/2001 od 14. siječnja 2004. Smatramo da je slobodan deklarirati njihovu inkompatibilnost s Ustavom te zabraniti provedbu na hrvatskom teritoriju. 
na "zakon", već i europsko pravo i međunarodne ugovore, u dijelu u kojem se sumnja na njihov (negativni) utjecaj na neku ustavnoidentitetsku komponentu.

Nadzornu ovlast Ustavnog suda valjalo bi konstruirati u svim onim slučajevima u kojima bi Simmenthal doktrina zahtijevala supstituciju ili prekluziju odredbe koja ili pripada katalogu ustavnoidentitetskih normi ili je vezana uz njihovu zaštitu. Dok god sidrimo svrhu čl. 37. UZUS-a u očuvanju vladavine prava, on je instrument zaštite ustavnog identiteta, pa nema potrebe da Ustavni sud čini posebne napore u uspostavi svoje nadležnosti na Identitätskontrolle (uključujući na zaštitu nepovredive srži nacionalnih jamstava ustavnih prava i sloboda). Sudbina Simmenthal doktrine u Hrvatskoj će, dakle, ovisiti o ozbiljnosti kojom će redovni suci prionuti identifikaciji slučajeva u kojima europski element ugrožava hrvatski ustavni identitet. Stoga će trebati naći i rješenje za slučajeve u kojima će nacionalni sudac propustiti zahtijevati intervenciju Ustavnog suda na temelju čl. 37. UZUS-a, tj. u kojima neće stati u zaštitu ustavnog identiteta te ce eventualno sniziti zaštitu temeljnih prava i sloboda. U takvoj situaciji plediramo za odvažno tumačenje čl. 63. UZUS-a i da se stranci koja smatra da su takvom odlukom povrijeđena njezina ustavna prava omogući prijevremeno podnošenje ustavne tužbe. Naime, nema dvojbe da je ustavno pravo "grubo povrijeđeno" u slučaju kad izuzimanje nacionalnog propisa dovodi do povrede jezgre ustavnog prava, $\mathrm{tj}$. do povrede ustavnog identiteta. Na stranci će ležati teret podnošenja prima faciae dokaza te povrede te će to pitanje trebati detaljnije razraditi ustavnim procesnim pravom.

\section{3. "Dvostruka preliminarnost"}

Kako bi, dakle, nacionalni sudac mogao razriješiti sukob čl. 37. UZUS-a i čl. 267. TFEU-a? Na temelju čega da odluči o davanju prednosti jednoj interlokutornoj kontroli nad drugom, tj. o trenutku komunikacije sa SPEU-om i Ustavnim sudom? U njegovim rukama leži konačna odluka s obzirom na to da stranke mogu samo predložiti takvo upućivanje zahtjeva (kako Ustavnom sudu, tako i SPEU-u). To ujedno znači da obrana nacionalnog ustavnog identiteta počiva na sudbenoj kulturi posvećenoj zaštiti vrednota konstitucionalizma, a ne vlastitog položaja ili institucionalnog prestiža ${ }^{105}$ Obrazovanjem i usavršavanjem sudačkih kadrova može se kontrirati nastojanju europskog prava da naruši lojalnost nacionalnih sudova vlastitim ustavima i zaobiđe primarnu ulogu ustavnih sudova $\mathrm{u}$ obrani nacionalnih vrednota.

${ }^{105}$ Komárek, op. cit. u bilj. 34, str. 17 - 18. 
Nacionalna implementacija članka 267. TFEU-a načelno pripada području procesne autonomije svake članice, omeđene zahtjevom za omogućavanjem njegova korisnog učinka. Čl. 267. stoga postavlja okvir za primjenu nacionalnih procesnih pravila. ${ }^{106}$ Čl. 37. UZUS-a ne sprečava sud u njegovu pristupu SPEU-u, pa tako ne utječe ni na mogućnost tzv. dvostruke preliminarnosti ${ }^{107}$ pri kojoj bi sudac tražio mišljenje i SPEU-a i Ustavnog suda. ${ }^{108}$ Talijanska praksa ide za razdvajanjem ovih zahtjeva, prednost dajući pristupu SPEU-a i čineći Ustavni sud nositeljem konačnog pravorijeka. ${ }^{109}$ Zamišljen kao mehanizam očuvanja nadređenosti nacionalnog ustavnog sudišta, taj se pristup izjalovio kada se pokazalo da talijanski suci ne smatraju ukupnu duljinu čekanja očitovanja i SPEU-a i Ustavnog suda procesno učinkovitom te se većinom zadovoljavaju samo odgovorom SPEU-a. ${ }^{110}$ Iako bi možda bilo u skladu s duhom čl. 37. UZUS-a, "talijansko" rješenje valja i kod nas odbaciti kao nepraktično i protivno jamstvu suđenja u razumnom roku. ${ }^{111}$ Čak i pod pretpostavkom da u Hrvatskoj ne bi iznjedrilo jednaku marginalizaciju Ustavnog suda, samo prethodni postupak pred SPEU-om je u 2016. godini prosječno trajao 15 mjeseci, čemu valja dodati i glečersku brzinu postupanja Ustavnog suda.

Obrnuto rješenje, u kojem bi čl. 267. TFEU-a bio aktiviran tek nakon odluke Ustavnog suda, nije prihvatljivo hrvatskom pravu s obzirom na obvezujuću narav odluka Ustavnog suda. Ono pak može biti u skladu sa Simmenthal mandatom jer su u predmetu Križan nacionalni sudovi ionako potaknuti na zanemarivanje

106 Petrašević, T.; Vuletić, I., Prethodni postupak pred Europskim sudom pravde i njegova implementacija u hrvatsko procesno pravo, Godišnjak Akademije pravnih znanosti Hrvatske, vol. 5, br. 1, 2014., str. 150.

107 Martinico, op. cit. u bilj. 17, str. 871.

108 Problem bi mogao predstavljati zaključak Ustavnog suda od 27. kolovoza 2013. (Rješenje U-I-4175/2013) kojim se korištenje čl. 37. UZUS-a odriče sucu pojedincu, opredjeljujući se za "institucionalni pristup" koji položaj pokretača postupka u smislu čl. 37. UZUS-a priznaje isključivo "tijelima”, a ne osobama koje nose odgovarajuće funkcije unutar njih (t. 9.1.). Ustavni sud dopušta da sudac smije potpisati zahtjev, ali da njega mora i svojim potpisom i pečatom suda poduprijeti njegov predsjednik (t. 9.2.). Oprečnost ovog te pristupa SPEU-a poražava nastojanja na formiranju sudbene kulture koja preferira dijalog s vlastitim ustavnim sudom.

109 Corte Costituzionale odbacuje podneske u slučajevima u kojima prethodno nije zatraženo mišljenje SPEU-a, Cartabia, op. cit. u bilj. 22, str. 24.

110 Ibid., str. 31.

111 Ovakav redoslijed bio bi ustavan ako bi se čl. 37. UZUS-a shvatio kao sredstvo osiguranja "posljednje riječi” Ustavnog suda. 
odluka vlastitih ustavnih sudova. ${ }^{112}$ Također, Melki i Abdeli ${ }^{113}$ jasno čini ustupak strogom tumačenju doktrine i dopušta da izuzimanje nacionalnog pravila bude privremeno odgođeno do nakon donošenja odluke Ustavnog suda. ${ }^{114}$ Iako vremenski gubitak i ovdje djeluje prohibitivno, takvo rješenje teoretski ostaje moguće. Realno bi ovakav détente SPEU-a mogao motivirati i druge članice na uspostavu interlokutorne ocjene ustavnosti, čineći je "novom bojišnicom europskog sudbenog dijaloga". ${ }^{115}$

Vrijedna je razmatranja, stoga, i treća opcija, u kojoj bi se dvije interlokutorne kontrole provodile istodobno. U ovom scenariju Ustavni sud bi u duhu otvorenosti prema europskom pravu bio motiviran i na sudjelovanje u postupku pred SPEU-om kao svojevrsni amicus curiae u svim postupcima u kojima bi bili tangirani elementi ustavnog identiteta. Njegovo uključenje u postupak po čl. 267. TFEU-a (suspendirajući djelovanje u vlastitom predmetu interlokutorne kontrole) omogućilo bi međusudbeni dijalog i procesnu učinkovitost. ${ }^{116}$ Smatramo

${ }^{112}$ C-416/10 Jozef Križan i drugi protiv Slovenská inšpekcia životného prostredia, [2013] EU:C:2013:8, t. 70 - 71 .

113 C-188/10 i C-189/10 Aziz Melki and Sélim Abdeli, [2010] ECLI:EU:C:2010:363.

114 Osim ako je riječ o situaciji u kojoj se ustavnost implementacijskog zakona osporava iz istih razloga iz kojih je upitna valjanost direktive na kojoj se zakon temelji. U tom slučaju pitanje valjanosti direktive (pri čemu monopol odlučivanja ima SPEU) ima prednost pred nacionalnom kontrolom ustavnosti (Melki i Abdeli, t. 56.); Rodin, op. cit. u bilj. 12, str. 27. Sudac na temelju europskog prava u svakom slučaju i dalje zadržava pravo da koristi čl. 267. TFEU-a "u bilo kojem stadiju postupka”, no ako to čini tek nakon dovršetka postupka ocjene ustavnosti, ima pravo prihvatiti privremene mjere zaštite subjektivnih prava koja izviru iz europskih normi. Također, on neovisno o ishodu interlokutornog postupka zadržava pravo da nacionalnu mjeru izuzme iz primjene, t. 57.

115 Rodin, ibid., str. 30.

116 Ovakvo sudjelovanje u postupku pred SPEU-om također bi nadomjestilo obavezu Ustavnog suda da i sam podnese zahtjev SPEU-u. Iako Francovich doktrina nikad nije primijenjena prema ustavnom sudu, odgovornost za štetu snose i sudovi posljednje instance koji ne poštuju obavezu na temelju čl. 267. TFEU-a, C-224/01 Gerhard Köbler v Republik Österreich, [2003] ECLI:EU:C:2003:513, t. 53 - 56. S druge strane, posljedice za državu mogu uslijediti i u situaciji u kojoj sudac izuzme iz primjene nacionalnu normu bez iščekivanja odluke Ustavnog suda (ili unatoč njoj). Smatramo da je sudac u takvoj situaciji dužan primijeniti st. 2. čl. 37. UZUS-a u smislu da o svojem postupku obavijesti Ustavni sud, koji bi u situacijama u kojima nalazi potencijalnu prijetnju ustavnom identitetu (posebno standardima zaštite ljudskih prava!) mogao primijeniti čl. 45. UZUS-a i privremeno obustaviti izvršenje sudske odluke. Ako utvrdi da je došlo do povrede ustavnog identiteta, primjena čl. 57. UZUS-a omogućila bi stranci da traži izmjenu sudske odluke. Ako se izmjenom 
da je to najbolji način doprinosa pluralističkoj strukturi europskog materijalnog "ustava" i načelu ustavne tolerancije. ${ }^{117}$ Stavovi Ustavnog suda o identitetskim sastavnicama Ustava već bi nužno bili formirani i zastupani u toku postupka pred SPEU-om, pa ne bi došlo do ugrožavanja prava stranaka na suđenje u razumnom roku. Ustavni bi sud istodobno govorio u ime ustavnih vrednota europskoj pozornici i pridržao si pravo konačnog pravorijeka.

O ovim opcijama hrvatsko pravo još uvijek šuti, kao žrtva izostanka političke volje za rješavanjem problema usklađivanja nacionalnih potreba s europskim zahtjevima. Riječ je o neodgovornom ponašanju, pri čemu pristajanje na budućnost stihijskih rješenja danih tek u slučaju sukoba Ustavnog suda i SPEU-a može donijeti samo polovična rješenja. Hrvatsko procesno zakonodavstvo suce redovnih sudova ovlašćuje na podnošenje zahtjeva za prethodnu odluku SPEU-u bez ikakve dodatne upute o kompatibilnosti takvog rješenja s obavezom istih na temelju čl. 37. UZUS-a. ${ }^{118}$ Valja reći da ni tu nije riječ o nekoj smislenoj strategiji hrvatskog zakonodavca s obzirom da čl. 267. TFEU-a ionako izravno ovlašćuje suce na tu vrstu dijaloga. Hrvatski sudovi zasad još slabo koriste mogućnost neposrednog pristupa SPEU-u, pa je od akcesije do kraja 2016. podneseno samo osam zahtjeva, i to isključivo od strane nižih sudova. ${ }^{119}$

\section{ZAKLJUČAK}

Razvoj europskog prava značajno je transformirao položaj ustavnih sudova, marginalizirajući ih putem savezništva SPEU-a s nižim sudovima i ignoriranja uloge ustavnog sudstva u održavanju ideala konstitucionalizma. Ovisno o nacionalnoj sudbenoj kulturi i lojalnosti ustavu, to savezništvo može fiksacijom na jedinstvo i učinkovitost europskog prava srozati višu nacionalnu razinu jamstava ljudskih prava. Iako nezamislivo u doba predmeta Van Gend en Loos, danas je učinak europskih politika na temeljna prava i slobode postao jedno od najvaž-

akta ne bi mogle otkloniti štetne posljedice, stranka bi na temelju čl. 58. st. 5. UZUS-a također mogla držati državu odgovornom za nastalu štetu.

117 Cartabia, op. cit. u bilj. 22, str. 4.

118 Vidi čl. 18. st. 3. - 5. Zakona o kaznenom postupku (Narodne novine, br. 152/2008, 76/2009, 80/2011, 121/2011, 91/2012, 143/2012, 56/2013, 145/2013, $152 / 2014$ i 70/2017), čl. 213. st. 2. Zakona o parničnom postupku (Narodne novine, br. 53/1991, 91/1992, 58/1993, 112/1999, 88/2001, 117/2003, 88/2005, 02/2007, 84/2008, 123/2008, 57/2011, 148/2011, 25/2013, 89/2014) i čl. 45. st. 2. Zakona o upravnim sporovima.

119 SPEU, Godišnji izvještaj za 2016. godinu, https://curia.europa.eu/jcms/upload/docs/ application/pdf/2017-03/ra_jur_2016_en_web.pdf (14. svibnja 2018.), str. 109 i 111. 
nijih bojnih područja prava EU-a. Načela skrojena u cilju ostvarenja ujedinjenog tržišta više nisu prikladna za diskurs temeljnih prava. Osobito je zabrinjavajuća tendencija SPEU-a da primjenjuje strože testove proporcionalnosti na nacionalne mjere, istodobno pokazujući mnogo više razumijevanja za akte Unije. ${ }^{120}$ Također teško spojiva s konstitucionalističkom logikom je tek povremena voljnost na žrtvovanje ekonomskih sloboda u ime zaštite ljudskog dostojanstva. Takva praksa prijeti "sudbenim kolonijalizmom" i centralizacijom obrane ljudskih prava na europskoj razini na način koji prazni zaštitu nacionalnih ustava i prelazi granice djelovanja kojih bi se tijela Unije morala pridržavati. ${ }^{121}$

Nužno je razmotriti učinke prava EU-a kako bismo izbjegli snižavanje standarda zaštite prava i sloboda. Iako disrupcija europske federalističke matrice mora biti ograničena, sudovi moraju biti ovlašteni na zanemarivanje odredaba prava EU-a koje ugrožavaju nacionalne identitete. Ustavnosudska Identitätskontrolle može održati funkcionalnu ravnotežu između očuvanja strukturnih odrednica nacionalne ustavne države i projekta europske integracije. U hrvatskim uvjetima, odvažna interpretacija čl. 37. UZUS-a može odgovoriti na zahtjeve tog izazova. Sidrenjem njegove funkcije u očuvanju ideala vladavine prava omogućili bismo njegovo širenje na nadzor nad usklađenošću europskih propisa s nepovredivim jamstvima Ustava, pogotovo (višim) nacionalnim standardima zaštite prava i sloboda. Poticanje sudova da istodobno koriste ovlasti pristupa Ustavnom sudu i SPEU-u gradilo bi most između sukobljenih mandata dvaju pravnih poredaka na način koji je otvoren prema pravu EU-a, dok pridržava "zadnju riječ" ustavnom sudištu. Republika Hrvatska ima definiran ustavni identitet i niti jedno tijelo vlasti (uključujući i narod) ne može njime raspolagati. Polazeći od te nepovredive srži Ustava i dužnosti sudstva na njegovu beskompromisnu zaštitu, obveza iskrene suradnje u nadnacionalnoj integraciji naroda obavezuje na iznalaženje proceduralnih mehanizama koji će toj zadaći pristupiti na koherentan način, u uvjetima dijaloga i međusobnog poštovanja.

${ }^{120}$ Cartabia, op. cit. u bilj. 22, str. 11.

121 Ibid., str. $16-17$. 


\section{LITERATURA}

\section{Znanstveni radovi i knjige}

Augenstein, D., "Integration Through Law" Revisited: The Making of the European Polity, Routledge, 2016., https://doi.org/10.4324/9781315589046

Bačić, A., Sudac i ustavna demokracija: dr.sc. Jadranko Crnić kao čuvar ustava, u: Kačer, H.; Momčinović, H.; Žuvela, M. (ur.), Liber amicorum in honorem Jadranko Crnić (1928.-2008.), Novi informator, 2009., str. 15-36.

Bartl, M.; Leone, C., Minimum Harmonisation after Alemo-Herron: The Janus Face of EU Fundamental Rights Review, European Constitutional Law Review, vol. 11, br. 1, 2015., str. 140-154, https://doi.org/10.1017/S1574019615000097

Besselink, L., National and Constitutional Identity Before and After Lisbon, Utrecht Law Review, vol. 6, 2010., str. 36-49, https://doi.org/10.18352/ulr.139

Cartabia, M., "Taking Dialogue Seriously": The Renewed Need for a Judicial Dialogue at the Time of Constitutional Activism in the European Union, Jean Monnet Working Paper, br. 12/07.

Chalmers, D.; Davies, G.; Monti, G., European Union Law: Cases and Materials, Cambridge University Press, 2010.

Claes, M., The National Courts' Mandate in the European Constitution, Bloomsbury Publishing, 2006.

Cloots, E., National Identity, Constitutional Identity, and Sovereignty in the EU, Netherlands Journal of Legal Philosophy, vol. 45, br. 2, 2016., str. 82-98, https:// doi.org/10.5553/NJLP/.000049

Ćapeta, T., Nacionalni ustav i nadređenost prava EU u eri pravnog pluralizma, Zbornik Pravnog fakulteta u Zagrebu, vol. 59, br. 1, 2009., str. 63-96.

Ćapeta, T., Ustavni acquis communautaire i ustavni poredak Republike Hrvatske, u: Kačer, H.; Momčinović, H.; Žuvela, M. (ur.), Liber amicorum in honorem Jadranko Crnić (1928.-2008.), Novi informator, 2009., str. 221-249.

Fabbrini, F., After the OMT Case: The Supremacy of EU Law as the Guarantee of the Equality of the Member States, German Law Journal, vol. 16, br. 4, 2015., str. 1003-1023, https://doi.org/10.2139/ssrn.2641800

Faraguna, P., Taking Constitutional Identities Away from the Courts, Brooklyn Journal of Constitutional Law, vol. 41, br. 2, 2016., str. 491-578.

Grimm, D., Defending Sovereign Statehood Against Transforming the Union into a State, European Constitutional Law Review, vol. 5, 2009., str. 353-373.

Horvat Vuković, A., "U ime Ustava” - materijalne granice promjene ustava, Zbornik Pravnog fakulteta u Zagrebu, vol. 65, br. 3-4, 2015., str. 481-503. 
Horvat Vuković, A., Referendum narodne inicijative 2013. - ustavni identitet kao okvir ustavnosudskog aktivizma, u: Podolnjak, R.; Smerdel, B. (ur.), Referendum narodne inicijative u Hrvatskoj i Sloveniji - Ustavnopravno uređenje, iskustva i perspektive, Hrvatska udruga za ustavno pravo, 2014., str. 149-177.

Isiksel, T., Europe's Functional Constitution: A Theory of Constitutionalism Beyond the State, Oxford University Press, 2016., https://doi.org/10.1093/acprof:o so/9780198759072.001.0001

Kaczorowska-Ireland, A., European Union Law, Routledge, 2016., https://doi. org/10.4324/9781315561035

Komárek, J., Why National Constitutional Courts Should Not Embrace EU Fundamental Rights, LSE Law, Society and Economy Working Papers 23/2014, https:// dx.doi.org/10.2139/ssrn.2510290

Kostadinov, B., Ustavni identitet, u: Barbić, J. (ur.), Dvadeseta obljetnica Ustava Republike Hrvatske, HAZU, 2011., str. 305-337.

Maduro, M.P.; Azoulai, L. (ur.), The Past and Future of EU Law: The Classic of EU Law Revisited on the 50th Anniversary of the Rome Treaty, Bloomsbury Publishing, 2010.

Martinico, G., Multiple Loyalties and Dual Preliminary: The Pains of Being a Judge in a Multilevel Legal Order, International Journal of Constitutional Law, vol. 10, br. 3, 2012., str. 871-896, https://doi.org/10.1093/icon/mos027

Millet, F.-X., National Constitutional Identity as a Safeguard of Federalism in Europe, u: Azoulai, L. et al. (ur.), Deconstructing EU Federalism through Competences, EUI Working Papers 2012/06, 2012., str. 53-65, https://dx.doi.org/10.2139/ ssrn.2068538

Omejec, J., Kontrola ustavnosti ustavnih normi (ustavnih amandmana i ustavnih zakona), Godišnjak Akademije pravnih znanosti Hrvatske, vol. 1, br. 1, 2001., str. 1-28.

Omejec, J., O potrebnim promjenama u strukturi hrvatskoj ustavnog sudovanja, u: Barbić, J. (ur.), Hrvatsko ustavno sudovanje, HAZU, 2009., str. 23-168.

Omejec, J., Study on European Constitutional Courts as the Courts of Human Rights: Assessment, Challenges, Perspectives, 3rd Congress of the Association of Asian Constitutional Courts and Equivalent Institutions, Bali, travanj 2016.

Petrašević, T.; Vuletić, I., Prethodni postupak pred Europskim sudom pravde i njegova implementacija u hrvatsko procesno pravo, Godišnjak Akademije pravnih znanosti Hrvatske, vol. 5, br. 1, 2014., str. 144-163.

Rasmussen, M., Revolutionizing European law: A History of the Van Gend en Loos Judgment, International Journal of Constitutional Law, vol. 12, br. 1, 2014. , str. 136-163, https://doi.org/10.1093/icon/mou006 
Rehman, J., International Human Rights Law, Pearson Education, 2010.

Rodin, S., Pravo Europske unije i pravni poredak Republike Hrvatske nakon 20 godina hrvatskog Ustava, Inter-University Centre of Excellence, Opatija, Working Paper H2/2010.

Rodin, S., Ustavni protekcionizam i nacionalni identitet, u: Ustavi i demokracija: strani utjecaji i domaći odgovori, HAZU, 2012., str. 145-174.

Schütze, R., European Constitutional Law, Cambridge University Press, 2012., https://doi.org/10.1017/CBO9781139031769

Smerdel, B., In Quest of a Doctrine: Croatian Constitutional Identity in the European Union, Zbornik Pravnog fakulteta u Zagrebu, vol. 64, br. 4, 2014., str. 513-534.

von Bogdandy, A.; Schill, S., Overcoming Absolute Primacy: Respect for National Identities Under the Lisbon Treaty, Common Market Law Review, vol. 48, 2011. str. 1417-1454.

Vranes, E., German Constitutional Foundations of, and Limitations to, EU Integration: A Systematic Analysis, German Law Journal, vol. 14, br. 1. 2013., str. 75-112, https://doi.org/10.1017/S2071832200001723

Weatherill, S., Use and Abuse of the EU'S Charter of Fundamental Rights: on the improper veneration of "freedom of contract", European Review of Contract Law, vol. 10, br. 1, 2014., str. 167-182, https://doi.org/10.1515/ercl-2014-0006

Weiler, J.H.H., The Transformation of Europe, Yale Law Journal, vol. 100, br. 8, 1991., str. 2403-2483.

\section{Sudska praksa}

Njemački Savezni ustavni sud, Lissabon, 2 BvR 2728/13, 2729/13, 2730/13, 273l/13 i 13/13

Njemački Savezni ustavni sud, Solange I, 2 BvL 52/7 I

Njemački Savezni ustavni sud, Solange II, 2 BvR 197/83

Sud pravde Europske unije, 106/77 Amministrazione delle Finanze dello Stato v. Simmenthal, [1978] ECLI:EU:C:1978:49

Sud pravde Europske unije, 11/70 Internationale Handelsgesellschaft v. Einfuhr- und Vorratsstelle für Getreide und Futtermittel, [1970] ECLI:EU:C:1970:114

Sud pravde Europske unije, 14/83 Sabine von Colson and Elisabeth Kamann v. Land Nordrhein-Westfalen, [1984] ECLI:EU:C:1984:153

Sud pravde Europske unije, 26/62 NV Algemene Transport- en Expeditie Onderneming van Gend \& Loos v Netherlands Inland Revenue Administration, [1963] ECLI:EU:C:1963:1 
Sud pravde Europske unije, 314/85 Foto-Frost v. Hauptzollamt Lübeck-Ost, [1987] ECLI:EU:C:1987:452

Sud pravde Europske unije, 4/73 J. Nold, Kohlen- und Baustoffgroßhandlung v Commission of the European Communities, [1974] ECLI:EU:C:1974:51

Sud pravde Europske unije, C-188/10 i C-189/10 Aziz Melki and Sélim Abdeli, [2010] ECLI:EU:C:2010:363

Sud pravde Europske unije, C-399/11 Stefano Melloni v Ministerio Fiscal, [2013] ECLI:EU:C:2013:107

Sud pravde Europske unije, C-416/10 Jozef Križan i drugi protiv Slovenská inšpekcia životného prostredia, [2013] EU:C:2013:8

Sud pravde Europske unije, C-426/11 Mark Alemo-Herron and Others v. Parkwood Leisure Ltd., [2013] ECLI:EU:C:2013:521

Sud pravde Europske unije, C-54/96 Dorsch Consult v. Bundesbaugesellschaft Berlin, [1997] ECLI:EU:C:1997:413

Sud pravde Europske unije, C-6/64 Flaminio Costa v. E.N.E.L., [1964] ECLI:EU:C:1964:66

Sud pravde Europske unije, C-617/10 Åklagaren v. Hans Åkerberg Fransson, [2013] ECLI:EU:C:2013:105

Talijanski Ustavni sud, Frontini v. Ministero delle Finance, odluka br. 183/73 od 18. prosinca 1973.

Ustavni sud Republike Hrvatske, Odluka U-I-3597/2010, U-I-3847/2010, U-I692/2011, U-I-898/2011 i U-I-994/2011 od 29. srpnja 2011.

Ustavni sud Republike Hrvatske, Odluka U-I-745/1999 od 8. studenog 2000.

Ustavni sud Republike Hrvatske, Odluka U-I-920/1995 i U-I-950/1996 od 15. srpnja 1998.

Ustavni sud Republike Hrvatske, Odluka U-II-6111/2013 od 10. listopada 2017.

Ustavni sud Republike Hrvatske, Odluka U-VIIR-1158/2015 od 21. travnja 2015.

Ustavni sud Republike Hrvatske, Odluka U-VIIR-1159/2015 od 8. travnja 2015.

Ustavni sud Republike Hrvatske, Odluka U-VIIR-4640/2014 od 12. kolovoza 2014.

Ustavni sud Republike Hrvatske, Upozorenje u povodu Prijedloga Odluke o raspisivanju državnog referenduma Odbora za Ustav, Poslovnik i politički sustav Hrvatskog sabora od 24. listopada 2013., U-VIIR-5292/2013 od 28. listopada 2013. 


\section{Propisi}

Charter of fundamental rights of the European Union, OJ C 303/17, 14. prosinca 2007.

Treaty on the European Union, OJ C 191/01, 29. srpanj 1992.

Ustavni zakon o Ustavnom sudu, Narodne novine, br. 99/99, 29/02 i 49/02

Zakon o upravnim sporovima, Narodne novine, br. 20/10, 143/12, 152/14, $94 / 16$ i $29 / 17$

\section{Internetski resursi}

Besselink, L., The ECJ as the European „Supreme Court“: Setting Aside Citizens” Rights for EU Law Supremacy, Verfassungsblog, 18. kolovoz 2014., na: http:// verfassungsblog.de/ecj-european-supreme-court-setting-aside-citizens-rights-eu-law-supremacy (14. svibnja 2018.)

Goos, C., Solange Zweieinhalb - Teil I, https://www.juwiss.de/14-2016/, 10. veljače 2016. (14. svibnja 2018.)

Hong, M., Solange III - Human Dignity and Constitutional Identity: The Solange-III-Decision of the German Constitutional Court, Verfassungsblog, https:// verfassungsblog.de/human-dignity-and-constitutional-identity-the-solange-iii-decision-of-the-german-constitutional-court/, 18. veljače 2016. (14. svibnja 2018.)

Leczykiewicz, D., Melloni and the future of constitutional conflict in the EU, UK Constitutional Law Association Blog, https:/ukconstitutionallaw.org/2013/05/22/dorota-leczykiewicz-melloni-and-the-future-of-constitutional-conflict-in-the-eu/ (14. svibnja 2018.)

Sarmiento, D., Awakenings: the „Identity Control“ decision by the German Constitutional Court, Verfassungsblog. https://verfassungsblog.de/awakenings-the-identity-control-decision-by-the-german-constitutional-court/, 27. siječnja 2016. (14. svibnja 2018.). 
Summary

\section{Ana Horvat Vuković *}

\section{THE CONSTITUTIONAL COURT OF THE REPUBLIC OF CROATIA AS A 'EUROPEAN' COURT AND THE PRESERVATION OF NATIONAL STANDARDS OF FUNDAMENTAL RIGHTS PROTECTION}

The author analyzes the phenomenon of national courts' function as European courts of first instance, and the system of dual loyalty toward the European and the national constitutional orders that it creates. With regard to a potentially higher constitutional level of protection of fundamental human rights and freedoms, as well as to Croatian constitutional identity, the author weighs the procedural avenues available for reconciling the EU Court's Simmenthal mandate and Art. 37 of the Constitutional Act on the Constitutional Court of the Republic of Croatia. Besides a fierce judicial loyalty to the Constitution, the author considers the dual preliminarity mechanism to be a viable compromise well within the national procedural autonomy, simultaneously triggering the interlocutory and preliminary ruling procedures before the Croatian Constitutional Court and the European Court (respectively). She stresses the ultimate supremacy of a national constitution and its identity, which must be allowed to prevail in all cases of irreconcilable differences between the European and the national viewpoints, the spirit of loyal cooperation and openness to European law notwithstanding. In that sense, the Constitutional Court of the Republic of Croatia must strengthen its constitutional identity doctrine, and assume a clear responsibility for constitutional review of European law against this benchmark.

Key words: Constitutional Court of the Republic of Croatia, Court of Justice of the European Union, Art. 37 of the Constitutional Act on the Constitutional Court of the Republic of Croatia, constitutional identity, fundamental rights and freedoms protection, dual preliminarity

Ana Horvat Vuković, Ph. D., Assistant Professor, Faculty of Law, University of Zagreb, Trg Republike Hrvatske 3, Zagreb; ana.horvat@pravo.hr;

ORCID ID: orcid.org/0000-0002-8451-5620 